\title{
Model investigations into assessing optimal power consumption modes for major pump stations of iron ore underground mines
}

\author{
Igor Sinchuk ${ }^{1}$, Tetyana Beridze $^{1}$, Irina Kasatkina ${ }^{1}$, Roman Krasnopolsky ${ }^{1}$, Oleg Dozorenko ${ }^{1, *}$, and Ryszard Strzelecki $^{2}$ \\ ${ }^{1}$ Kryvyi Rih National University, Department of Automated Electrical-Mechanical Systems in Industry and Transport, 11 Vitalii \\ Matusevych Str., Kryvyi Rih, 50027, Ukraine \\ ${ }^{2}$ Gdańsk University of Technology, Department of Power Electronics and Electrical Machines, 11/12, Gabriela Narutowicza 80-233 \\ Gdańsk, Poland
}

\begin{abstract}
The article investigates into the level of energy efficiency of main water pump stations of iron ore underground mines in case of time-of-day electricity rate. There are developed and suggested methods of analyzing the influence of pump electric capacity on electricity cost based on multifactor regressive models. The data on power consumption of iron ore mines indicates a complex character of analyzing the results obtained. However, application of information technologies enables using static materials in a new way including indices of power consumption, costs, water intake, mining depth, the number of pumps and their capacity by synthesizing mathematical models as complicated objects through in-depth procession of static materials and substantiation of the obtained results. For the first time, there are used multifactor regressive models considering multicollinearity and non-linearity of pump capacity in order to study its influence on power costs by using the elasticity factor. Analysis of mathematical simulation results relevant to static materials and applying the algorithm of studying dependency of the consumed power costs on pumps' capacity reveals some critical values resulting in corresponding effects. The authors recommend to apply the elaborated algorithm to conducting corresponding calculations by for mining enterprises to monitor formation of the strategy of providing energy efficiency under time-of-day electricity rates.
\end{abstract}

\section{Introduction}

Mining enterprises are considered energy-intensive or, to be exact, electric power-intensive [1-4]. The fact that power makes about $90 \%$ of the whole energy consumption and over $30 \%$ of the cost forms the basic component of the current level and constantly increasing power-intensity of mineral mining, thus negatively affecting mining enterprises' economy and their competitive character on the international market of raw materials [3-5].

The characteristic of the research object. The problem of controlling power supply and consumption in terms of some technological factors is challenging and real-life among other issues of reducing energyintensity of mineral mining [6-7]. To do this, there are some positive steps taken at mining enterprises including ore underground mines. Among those, are a limited number of energy-intensive consumers consuming about $90 \%$ of the total power (Fig. 1) [8, 9]. Facts like these a priori are highlighting the vectorrelated character of developing the strategy of researching into control over powersupply/consumption of such enterprises by transforming energy-intensive consumers into power regulators [810]. Besides, this process is stimulated by the Law on power in Ukraine which has actually intensified the 'power load' on mining enterprises, thus enhancing this process [8].

\section{Research materials}

Analysis of distributing power consumption levels among energy-intensive consumers of iron ore underground mines enables or rather testifies to the individual character of each enterprise (Fig. 1).

Without generalizing solutions to the energyefficiency problem of all energy-intensive consumers of iron ore underground mines, from all the mentioned issues (Fig. 1), we focus on investigating into power consumption and control levels of major pump stations.

According to Fig. 1, Batkivshchina mine has the highest power consumption level, while Hvardiiska the lowest. It should be noted that besides typical conditions of pump stations, unlike other power consumers, they are noted for functioning not only in periods of enterprises' active operation, but also after their full or partial conservation (closure) [3-5].

It is essential to accentuate that power consumption of pump stations at non-operating underground mines is actually higher than that of operating ones (Fig. 2-3) [9-

*Corresponding author: ol.dozorenko2017@gmail.com 
12]. At some underground mines, systems of underground water pumping are often combined into a single power complex. This causes some additional aspects affecting the choice of a pumping scheme design and operation modes of corresponding equipment.



a)



b)

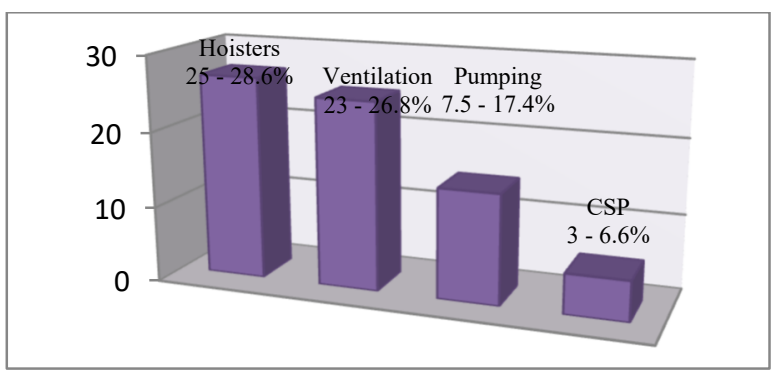

c)



d)

Fig. 1. Variations of power consumption levels by types of mine consumers: $\mathrm{a}$ - Zhovtneva, $\mathrm{b}-$ Batkivshchina, $\mathrm{c}-$ Hvardiiska, d - Ternivska.

Yet, the basic component forms the foundation for the pumping structure of an individual underground mine and remains as given in Table 1.

According to Fig. 2-3, power consumption levels do not change greatly form year to year and tend to be stable.

Energy efficiency of underground mining enterprises' pump stations can be enhanced by:

- improving the technology of their 24-hour functioning and transferring them from the maximum pumping to a more economical mode of power consumption;

- creating return-water pump stations.

The latter will allow mining enterprises to generate their own electric power. The algorithm of major pump stations functioning is as follows: during 'economical time periods' water is pumped from the mine into the surface to corresponding water storage ponds, while during 'non-economical' ones, part of water from those ponds is pumped to the mine and pump motors start generating power [11-14].

Table 1. Established capacity of motors at Kryvyi Rih underground mines.

\begin{tabular}{|c|c|c|c|}
\hline Mine & \multicolumn{3}{|c|}{ Motors } \\
\hline \multirow{4}{*}{ Ternivska } & Capacity, kW & Number & $\begin{array}{c}\text { Total capacity, } \\
\mathrm{kW}\end{array}$ \\
\cline { 2 - 4 } & 800 & 9 & 7200 \\
\cline { 2 - 4 } & 315 & 4 & 1260 \\
\cline { 2 - 4 } & 250 & 4 & 1000 \\
\hline \multirow{4}{*}{ Hvardiiska } & & & Total 9460 \\
\cline { 2 - 4 } & 600 & 9 & 7200 \\
\cline { 2 - 4 } & 500 & 3 & 1890 \\
\cline { 2 - 4 } & 315 & 3 & 500 \\
\hline \multirow{3}{*}{ Zhovtneva } & & & 945 \\
\cline { 2 - 4 } & 400 & 8 & 6400 \\
\cline { 2 - 4 } & & 8 & 3200 \\
\hline \multirow{3}{*}{ Batkivshchina } & 800 & 20 & 16000 \\
\cline { 2 - 4 } & 560 & 6 & 3360 \\
\cline { 2 - 4 } & & & Total 19360 \\
\hline
\end{tabular}

In other words, the power supply complex structure is transformed into the distributed power generation pattern [8].

With that, it is also necessary to develop (elaborate) the structure of pump stations' functioning under the power generation mode and upgrade the pump stations themselves both under the pumping mode and the power generation one.

To analyze the given process, one should develop mathematical models to analyze and elaborate trends of implementing theoretical results.

It is possible by introducing modern system-based approaches and mathematical and statistical methods.

By analyzing power consumption of pump stations, we can identify basic impact factors for individual iron ore underground mines (Table 2) [15-19].

While treating a power-consuming object (an underground mine) as a structural scheme, we can single out some input changes with controlling and disturbing actions of a corresponding energy-intensive unit, while the total electricity load of a mine is an output value.

In its general form, the mathematical model of the iron ore underground mine's consumption can be set by the function of input variables [6]:

$$
P_{\Sigma}=F\left(v, n_{i}, Q_{j}, Q_{m}, q_{j}, R_{j}\right)
$$

where $P_{\Sigma}$ is the total electric load of a mine, $\mathrm{kW} / \mathrm{year} ; v$ is intensity of the skip hoister functioning, $\mathrm{t} /$ year; $n_{i}$ is the number of operating pumps at the $j$-th pumping stage, units; $Q_{j}$ is efficiency of the $j$-th mine fan, $\left(\mathrm{m}^{3} / \mathrm{sec}\right) ; Q_{u}$ is total efficiency of underground mining 
sites, (t/year); $q_{j}$ is water inflow for the $j$-th pumping stage, $\left(\mathrm{m}^{3} / \mathrm{sec}\right) ; R_{j}$ is resistance of the fan network of the



a)



c) $j$-th main mine fan. For model (1) variables $v, n_{j}, Q_{j}$ are controlling, while $Q_{u}, q_{j}, R_{j}$ are disturbing.



b)

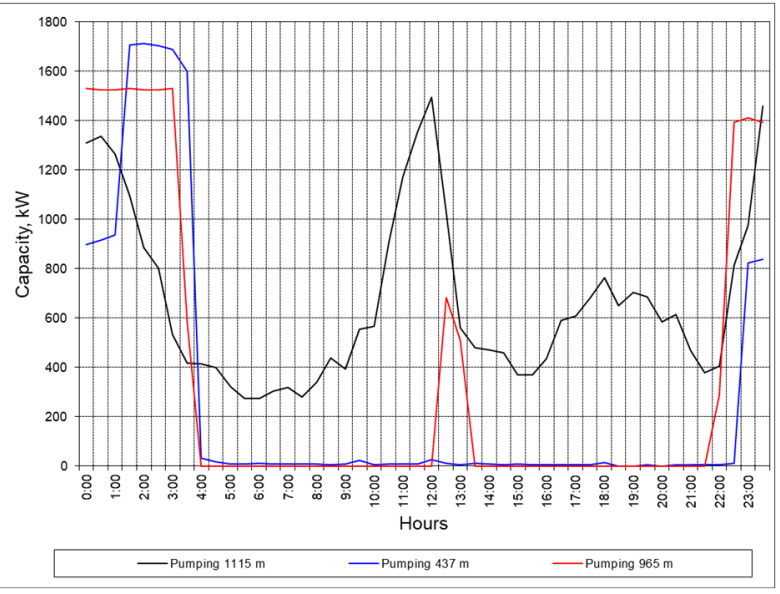

d)

Fig. 2. Power consumption levels at major pump stations of some Kryvyi Rih iron ore mines in May 7, 2012: a - Ternivska, b Hvardiiska, c - Batkivshchina, d - Zhovtneva.

Table 2. Basic factors impacting Kryvyi Rih iron ore mines' power consumption.

\begin{tabular}{|c|c|c|c|c|c|c|c|c|}
\hline \multicolumn{3}{|c|}{$\begin{array}{c}\text { Power consumption of pump } \\
\text { stations, } \mathrm{kW} / \text { year }\end{array}$} & \multirow[t]{2}{*}{$\begin{array}{r}\text { Mining } \\
\text { depth, m }\end{array}$} & \multicolumn{3}{|c|}{ Water inflow, $\mathbf{m}^{3}$} & \multirow[t]{2}{*}{$\begin{array}{c}\begin{array}{c}\text { Number } \\
\text { of pumps, } \\
\text { units }\end{array} \\
\end{array}$} & \multirow[t]{2}{*}{$\begin{array}{l}\text { Capacity, } \\
\text { kW }\end{array}$} \\
\hline 2014 & 2015 & 2016 & & 2014 & 2015 & 2016 & & \\
\hline \multicolumn{9}{|c|}{ Ternivska } \\
\hline 11307677 & 10742330 & 8984057 & 1350 & 1585407 & 1494432 & 1211279 & 4 & 315 \\
\hline \multicolumn{9}{|c|}{ Hvardiiska } \\
\hline 9888508 & 8258434 & 6556150 & 1350 & 1310352 & 1136586 & 844396 & 3 & 315 \\
\hline \multicolumn{9}{|c|}{ Zhovtneva } \\
\hline 1037486 & 9293986 & 8482342 & 1265 & 1466460 & 1273886 & 1167783 & 1 & 400 \\
\hline \multicolumn{9}{|c|}{ Batkivshchina } \\
\hline 25801367 & 26878130 & 25583364 & 1465 & 4416601 & 4619121 & 4394257 & 4 & 800 \\
\hline
\end{tabular}

According to established formalization, power consumption of pump stations can be set as:

$$
P_{\Sigma}=F\left(v_{1}, n_{i}, q_{j}, R_{j}\right)
$$

where $P_{\Sigma}$ is total power load of corresponding pump stations, $\mathrm{kW} /$ year; $v_{1}$ is a level, $\mathrm{m} ; n_{i}$ is the number of operating pumps at the $j$-th pumping stage, units; $q_{j}$ is water inflow for the $j$-th pumping stage, $\left(\mathrm{m}^{3} / \mathrm{sec}\right) ; R_{j}$ is capacity, $\mathrm{kW}$.
For (2), variables $v_{1}, n_{i}, Q_{i}$ are controlling, while $R_{j}$ is disturbing.

After considering the diagram of total power load realization of various combinations of input variables and recognizing dependency of power consumption of corresponding pump stations on controlling and disturbing actions, we can control functioning of the energy-intensive station according to the set criterion. 




a)

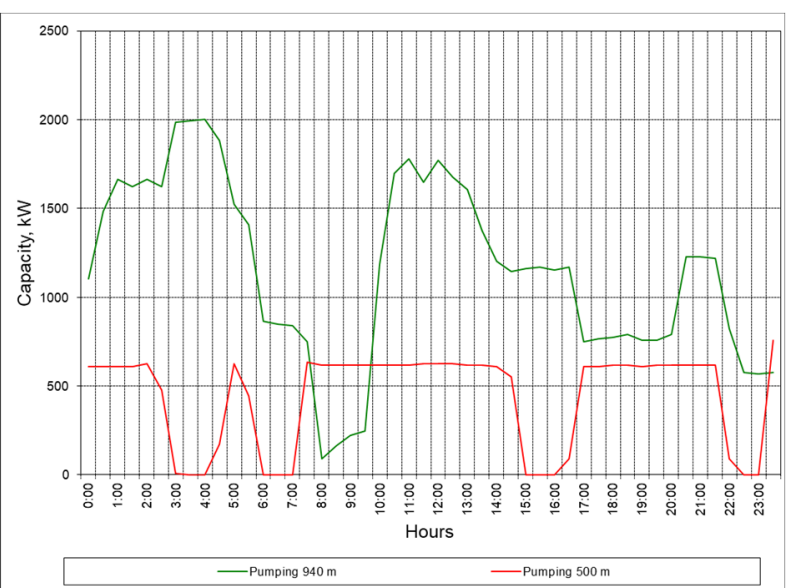

c)



b)

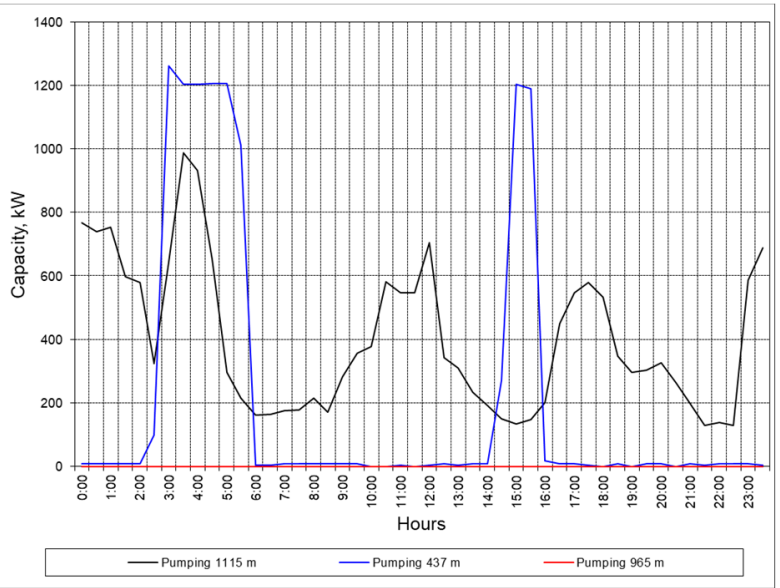

d)

Fig. 3. Power consumption levels at major pump stations of some Kryvyi Rih iron ore mines in February 15, 2019: a - Ternivska, b - Hvardiiska, c-Batkivshchina, d - Zhovtneva.

The simplified two-area time-of-day rate can be written as:

$$
C_{\Sigma}=C_{\partial}+C_{H}
$$

where $C_{\partial}, C_{H}$ are expenditures considering two-area (day, night) rates, $U A H$.

Besides, we can write:

$$
C_{\Sigma}=C_{1} \cdot W_{\Sigma}, C_{H}+C_{2} \cdot W_{\Sigma}
$$

where $C_{1}, C_{2}$ are area rates, $U A H / \mathrm{kW}$.

According to [9], the maximum effect of controlling consumption is achieved by reducing loads in peak hours of the power system. In this case, the formula for expenditures required to minimize loads for pump stations can be set as the criterion:

$$
C=\frac{C_{1}}{T_{1}} \int_{0}^{T_{1}} P_{\Sigma}(t) d t+\frac{C_{2}}{T_{2}} \int_{0}^{T_{2}} P_{\Sigma}(t) d t \rightarrow \min
$$

where $T_{1}, T_{2}$ are selected intervals of day and night hours, hours.

Thus, the problem involves finding values controlling variables $v_{1}(t) ; n_{i}(t) ; g_{i}(t)$ which, with set values of disturbing actions $R_{j}$ will form the diagram of power consumption $P_{\Sigma}(t)$ that will have the criterion at least (4). The choice of values of controlling actions should consider some technological constraints associated with continuity of the process and provision of standard working conditions at an underground mine. The conditions include:
- keeping the accumulating underground bunker unfilled:

$$
\int_{0}^{T} Q_{u}(t) d t=\int_{0}^{T} v(t) d t
$$

- keeping the water level in water storage ponds stable:

$$
\sum_{j=1}^{n} \int_{0}^{T} q_{j}(t) d t=\sum_{j=1}^{n} \int_{0}^{T} Q_{n j} \cdot n_{j}(t) d t,
$$

where $Q_{n j}$ is efficiency of a pump of the $j$-th pumping rate, $m^{3} / \mathrm{sec} ; n$ is the number of pumping stages.

Real-time solution to the given problem with constraints (5) and (6) calls for application of calculation controlling devices and industrial programming controllers. On the first stage, they should forecast power consumption of an underground mine and provide a controller with recommendations for taking relevant controlling actions.

Meanwhile, reduction of criterion (4) in a general form is quite a complicated task even when applying computers. To simplify this problem, it is expedient to divide total target function (4) into local target functions.

The solution provides for in-depth preliminary analysis of the factor research.

For comparative analysis, we use Z-scaling to obtain a single interpretation system for indices equaling from 0 to $\mathrm{N}$.

By way of illustration, we accentuate the research conducted at Batkivshchina mine with the largest water 
inflow among underground mines of Kryvyi Rih iron ore basin. Thus, we obtain the following diagram:



Fig. 4. Dependency of power consumption and its cost on the time of the day.

Visual analysis of the diagram enables stating some correlation of power costs and time-of-day power rates (Fig. 4). Yet, after totaling the output data, we observe excessive power costs for area power rates in comparison with the two-area one. In other words, it is expedient to conduct a multifactor research into power consumption. In a general case, the form of the multifactor regressive model is indefinite. Yet, while investigating into efficiency of power consumption, it is reasonable to use a linear form of a model structure representing it in an additive manner. On the basis of Batkivshchina mine data, $\hat{Y}$ is the consumed power cost (UAH), $x_{1}$ is water inflow ( $\mathrm{m}^{3} /$ year), $x_{2}$ is mining depth (m), $x_{3}$ is the number of pumps (units), $x_{4}$ is motor capacity $(\mathrm{kW})$ [9-12],

$$
\hat{Y}=a+a_{1} x_{1}+a_{2} x_{2}+a_{3} x_{3}+b x_{4}^{2}+\varepsilon,
$$

where $a, a_{1}, a_{2}, a_{3}, b$ are parameters; $\varepsilon$ is uncontrolled disturbance.

The next step of building the model involves identification of parameters through determining their values that are included into (7).

Processing output data in MS Excel enables identifying these parameters by the least-square method.

The multifactor regressive model results in the following (7).

To identify multicollinearity, according to the output data, we build a correlation matrix of input variables.

$$
R=\left(\begin{array}{cccc}
1 & 0,886 & 0,702 & 0,572 \\
0,886 & 1 & 0,665 & 0,611 \\
0,702 & 0,665 & 1 & 0,420 \\
0,572 & 0,611 & 0,420 & 1
\end{array}\right)
$$

Analysis of correlation table (8) reveals that there is a close correlation between variables $x_{1}$ and $x_{2}$ which indicates multicollinearity. As the variable $x_{1}$ can be expressed by $x_{2}$, the variable $x_{1}$ can be excluded from input variables. The correlation matrix of input variables results in the following:

$$
R_{1}=\left(\begin{array}{ccc}
1 & 0,665 & 0,611 \\
0,665 & 1 & 0,420 \\
0,611 & 0,420 & 1
\end{array}\right)
$$

Analysis of correlation matrix (9) indicates no close correlation between input variables, i.e. there is no multicollinearity.

In the given research, it is reasonable to apply a linear model representing it in an additive form.

Identification of model parameters by processing the corresponding statistic materials enables finding these parameters by means of the least-square method. Multifactor regressive model (9) results in:

$$
Y=-0,391 x_{2}+2,728 x_{3}+33,23 x_{4}
$$

With that, the determination factor makes $R^{2}=$ 0.824 , while the Fischer criterion is $F=14.1$. The table value of the Fischer criterion is $F_{T}(0,05 ; 3 ; 8)=4,07$. As $F=14,1>F_{T}(0,05 ; 3 ; 8)=4,07, \quad$ equation $\quad(10)$ statistically significant.

Absence of the nonlinear member for pump capacity indicates a monotonous character of dependency of power costs on pump capacity.

Thus, on the basis of the simulation results for Batkivshchina mine, it is expedient to conclude that the influence of pump capacity on power costs is positive, i.e. it increases this value. With that, elasticity of power costs in compliance with pump capacity is calculated by:

$$
E_{Y / x_{4}}=\frac{33,23 x_{4}}{-0,391 \bar{x}_{2}+2,728 \bar{x}_{3}+33,23 \bar{x}_{4}},
$$

Fig. 5 shows the diagram of function (11).

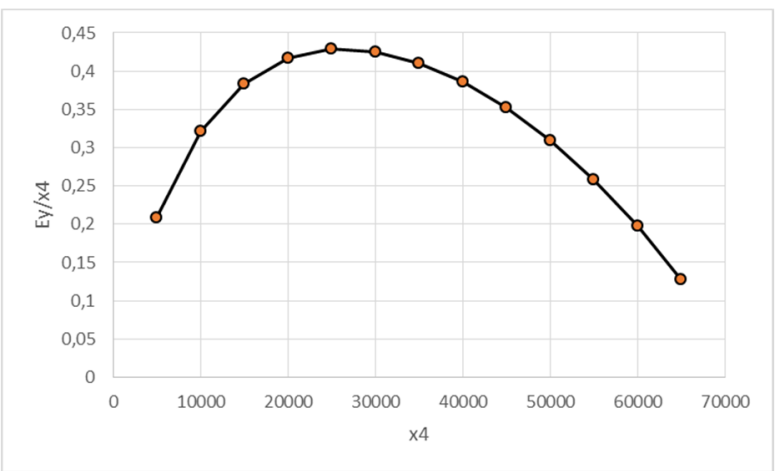

Fig. 5. Elasticity of power costs by pump capacity at Batkivshchina underground mine.

Analysis of Fig. 4 reveals that elasticity depends on power costs in compliance with motor capacity of Batkivshchina mine being positive and increases monotonously. Thus, there are developed methods of economic and statistical analysis that enable obtaining high-quality evaluation by using critical power costs depending on motor capacity as well as assessing its influence on power costs.

\section{Conclusions}

1. The suggested methods involve innovative approaches to evaluating power costs for operating pump stations of iron ore underground mines.

2. Application of modern IT enables digital methods of processing statistic data of power consumption indices including consumed electricity costs, the water inflow 
level, the mining depth, the number of pumps and capacity of motors.

3. After synthesizing mathematical models as complex objects, the authors assess the influence of pump capacity on power consumption and conduct numerical analysis by using the elasticity factor to determine dependency of power costs on the capacity index of pump motors. This approach is worth applying in practice to forming the strategy of providing energy efficiency with time-of-date electricity rates.

\section{References}

1. S.P. Denisyuk, Energoefektivnist Ukrayini: problemi ta shlyahi yiyi zrostannya [Energyefficiency of Ukraine: problems and ways of development]. Energetika: ekonomIka, tehnologiyi, ekologiya 4 (50), 7-28 (2017).

2. Denisyuk, S.P., Kotsar, O.V., \& Chernetska, Yu.V. (2016). Energetichna efektivnist Ukrayini. Kraschi proektni ideyi Proekt «Profesionalizatsiya ta stabilizatsiya energetichnogo menedzhmentu $\mathrm{V}$ Ukrayini [Energy efficiency in Ukraine. The best project ideas. The project Professionalization and stabilization of energy management in Ukraine]. Kyiv: KPI im. Sikorskoho (in Ukrainian).

3. Sinchuk O.N., Sinchuk I.O., Huzov, E.S., et al (2016). Elektroeffektivnost proizvodstv $\mathrm{s}$ podzemnyimi sposobami dobyichi. Monografiya [Energy-efficiency of underground mining enterprises]. Riga: LAP LAMBERT Academic Publishing (in Russian).

4. Sinchuk, I. O., Karamanyts, F. I., Osadchuk, Yu. G., et al (2019). Electric engineering of iron ore underground enterprises. Current status and prospects. Multi-authored monograph. Edited by DSc., Prof. O.M. Sinchuk. Warsaw: iScience Sp. z o. 0 .

5. Sinchuk, I. (2018). Harmonization of modeling systems for assessing the electric-power consumption levels at mining enterprises, Mining of Mineral Deposits, vol. 12, no. 4, pp. 100-107. doi:10.15407/mining 12.04.100.

6. Sinchuk, I. O., Boiko, S. M., M. L. Baranovska, et al (2019). Brief commentaries on the problem of power consumption management at iron ore underground mines. Multi-authored monograph. Edited by DSc., Prof. O.M. Sinchuk. Warsaw: iScience Sp. z o. o.

7. Sinchuk, O., Kupin, A., Sinchuk, I., Rohoza, M., Plieshkov, P. (2020). Certain aspects concerning the development of a functioning scheme of the auto-mated system to control energy flows of underground iron-ore enterprises, Mining of Mineral Deposits, vol. 14, no. 3, pp. 101-111, 2020. doi:10.33271/mining14.03.101.

8. Sinchuk, I.O. (2019). MetodologIchnI zasadi otsInyuvannya elektroefektivnostI zalIzorudnih pIdpriEmstv [Methodological foundations of energy-efficiency of iron ore mining enterprises]. Kremenchuk: PP Shcherbatykh (in Ukrainian).
9. Razumnyiy, Yu.T. (2004). Problemyi ispolzovaniya vodootlivnyih ustanovok ugolnyih shaht $\mathrm{V}$ kachestve potrebiteley-regulyatorov [Problems of applying pump stations of coal mines as consumers-regulators]. Hirnycha sprava Mining, 73, pp. (in Russian).

10. Rukhlova, N.Yu. (2014). Modelirovanie energoeffektivnyih rezhimov rabotyi shahtnogo vodootliva [Simulation of energy-efficient pumping modes for underground mines]. Proceeding from the International conference "Forum girnikiv - 2014", October 1-4, 2014, pp. 160-163. Dnepropetrovsk: TOV LIzunovPres (in Russian).

11. Kholomenyuk, M.V. (2007). Metodika rozrahunkIv vodovidlivnih ustanovok girnichih pIdpriemstv: metodichni vkazivki dlya studentiv napryamu pwIdgotovki 0902 Inzhenerna mehanIka [Methods of calculations for pump stations of mining enterprises: methodological guidelines for mechanical engineering students], Dnipro: Natsionalniy girnichiy universitet (in Ukrainian).

12. Ruhlova, N.Yu. (2012). O probleme effektivnogo elektropotrebleniya glavnyim vodootlivom shahtyi [On the problem of energy efficiency of major pump stations at underground mines]. Girnicha elektromehanIka ta avtomatika - Mining electromechanics and automation, 89, pp. 143-145 (in Russian).

13. Kopnova, E. D., \& Rodionova, L.A. (2016). Statisticheskie podhodyi $\mathrm{k}$ analizu i prognozirovaniyu demograficheskih dannyih [Statistical approaches to analyzing and forecasting demographic data]. Izvestiya Sarat. un-ta Proceedings from Saratov University,16, pp. 306315 (in Russian).

14. Lokhman, N. Serebrenikov, V. Beridze, T. Cherep, A. \& Dashko, I. (2020). Analysis of economic and mathematical modeling of industrial enterprise functioning at multicollinearity based on parameterization. Naukovyi Visnyk Natsionalnoho Hirnychoho Universytetu - Scientific Journal of National Mining University, 2, pp. 179-189.

15. SMIDA, Account of information services. Reports of enterprises. http://smida.gov.ua/ (n.d.)

16. State Statistics Service of Ukraine (n.d.). http://www.ukrstat.gov.ua/

17. T.M. Beridze, V.M. Serebrenykov, N.V. Lokhman, Monitoring of production activity of enterprises of Kryvyi Rih region. Ekonomika ta suspilstvo 15 . Retrieved from (2018)

18. V. Prokhorova, V. Protsenko, Y. Bezuglaya, Us, J. The optimization algorithm for the directions of influence of risk factors on the system that manages the potential of machine building enterprises. Eastern-European Journal of Enterprise Technologies 4 (1-94), 6-13 (2018)

19. K. Karlsberg, Regressionnyiy analiz v Microsoft Excel (Regression analysis in Microsoft Excel). (Williams, Moscow, 2017) 